\title{
温暖多照地域における全蓋型アーケード内部の気温分布性状 FILED INVESTIGATION ON AIR TEMPERATURE DISTRIBUTION INSIDE AN ENCLOSED ARCADE LOCATED IN THE AREA WITH MILD AND SUNNY CLIMATE
}

\author{
辻原 万規彦*, 中村泰 人**, 田中 稔***, 大塚順 基* \\ Makihiko TSUJIHARA, Yasuto NAKAMURA, Minoru TANAKA \\ and Junki OHTSUKA
}

\begin{abstract}
Air temperature distribution inside an enclosed arcade located in the area with mild and sunny climate was investigated on field observations both in summer 1995 and in winter 1996. Air temperature at the height of 0.5 meter in the occupied zone was a little higher than outside air temperature excluding the daytime to the evening in summer. Vertical distribution of air temperature showed a slope of high temperature in the upper part and low temperature in the lower part, in which the degree of the gradient was proportional to the amount of solar radiation and the magnitude depended on the rate of ventilation.
\end{abstract}

Keywords: Arcade, Air temperature, Vertical distribution, Solar radiation, Ventilation アーケード，気温，垂直分布，日射，換気

\section{1.はじめに}

日本各地で見られるアーケードをもつ商店街は，一般的に都市 の中心部にあり、アーケードは都市内公共空間を構成するととも に都市景観をも形成する重要な都市施設であると捉えられる。ま た,アーケードの内部空間をはじめとする都市における半戸外空 間は，厳しい外部環境を楥和し，利用者に対して快適な空間を提 供することが本来の目的であったと考えられる。しかしながら， 夏季においてアーケード内部の温熱環境について不満の声がある など，十分な整備ができていないのが現状である。

ところで,アーケードに類似した空間と考えられるアトリウム 内部の環境については，すでに多くの調査拉よび研究がなされて いる ${ }^{1)}$ 2)。それに反して，アーケードに関するものは現状ではほ とんど見られないため，基礎資料の収集が研究の第一歩とならざ るを得ない。

したがって本研究では, 温暖多照な地域に位置するアーケード を対象とし，その内部の温熱環境についての特性を測定によって 把握し，今後のアーケードの整備および改善のための基礎資料と して定着させることを目的とする。測定に際しての視点は，1） アーケード内部の気温分布性状の把握，2）アーケード内部の温 熟環境に扔ける快適性の評価，とし，本稿ではこのうち1）を扱
い，2）については稿を改める。

なお本稿は，文献）および4）で発表した内容に修正・加筆を 行ったものである。

\section{2. 対象アーケードの概要}

建設省通達におけるアーケード設置基準 ${ }^{5)}$ では「「アーケード」 とは日よけ，雨よけ，又は雪よけのため，路面上に相当の区間連 続して設けられる公益上必要な建筑物，工作物その他の施設をい う。」と定義され，そのうちさらに「道路の一側又は両側に設け るアーケード」および「道路の全面又は大部分をおおうアーケー ド」に分けられている。本研究では，このうち「道路の全面をお おうアーケード」を対象とした。

類似した空間と考えられるアトリウムと比較した場合，アーケー ドは温熱環境の観点から，以下のような特徵を持つと考えられる。

1) 屋根面を半透明または透明の合成樹脂素材で莫くことが多く, そのため内部環境はアトリウム同様，日射の影響を強く受け る。

2 ）鉛直方向には，100mを越える天井高を持つ場合もあるアトリ ウムに比較して，アーケードの天井高は高くても10１5 $\mathrm{m}$ 程 度であるが，氷平方向には長い空間を形成している場合が多
* 京都大学大学院工学研究科環境地球工学専攻 博士後期課程・修士 (工学)

** 京都大学大学院工学研究科環境地球工学専攻 教授·工博
Graduate Student, Dept. of Global Environment Engineering, Graduate School of Engineering, Kyoto University, M. Eng.

Prof., Dept. of Global Environment Engineering, Graduate School of Engineering, Kyoto University, Dr. Eng.

Kamimura Iron Works Co. Ltd. 


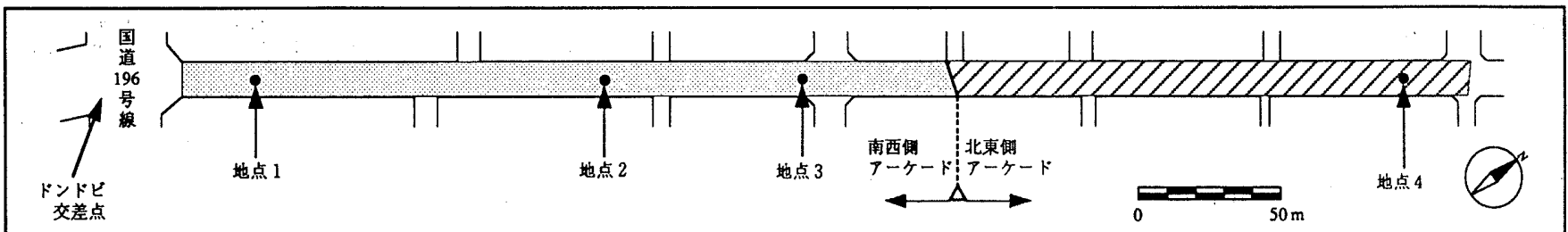

図 1 測定対象アーケードと測定地点

い。従ってアトリウムに比較して, 内部の全空間に対する, 居住域（人々が利用する空間）の比率が高い。

3）アトリウムと比較して周囲との境界があいまいであり, 多く の隙間が見られ，時には大きな開口部さえ持つ。

4) アーケード自体には基本的に空調設備を備えていない。さら に換気については，ほとんどの場合，自然換気のみであるが, 温熱環境を考慮した換気装置を備えているわけでななく，防 災上の排煙装置のみである。

測定対象としたアーケードを持つ商店街（図1）は，愛媛県今 治市の中心地ドンドビ交差点側を起点とし，そこから北東方向へ と伸び, 同市の中心商店街の一部を形成している。この商店街は 総延長約 $450 \mathrm{~m}$ の直線状の商店街であるが, アーケードの完成年度 の違いによる形式の相違で 2 部分に分けられている。南西側のアー ケードは1988年完成で, 延長約 $265 \mathrm{~m}$, 高さ約 $12 \mathrm{~m}$, 幅員約 $12 \mathrm{~m}$, 屋根面は厚さ $3.0 \mathrm{~mm}$ の乳白色ポリカーボネイト樹脂板である。北 東側のアーケードは1980年の完成で, 延長約 $185 \mathrm{~m}$, 高さ約 $10 \mathrm{~m}$, 幅員約 $12 \mathrm{~m}$, 屋根面は厚さ $1.2 \mathrm{~mm}$ の乳白色ガラス瀻維強化ポリエ ステル小波板である。またアーケードが設置されたところは，指 定車・許可車を除いては通行が禁止されている歩行者用道路では あったが，特に午前中には般入用車両の通行が，また夜間には一

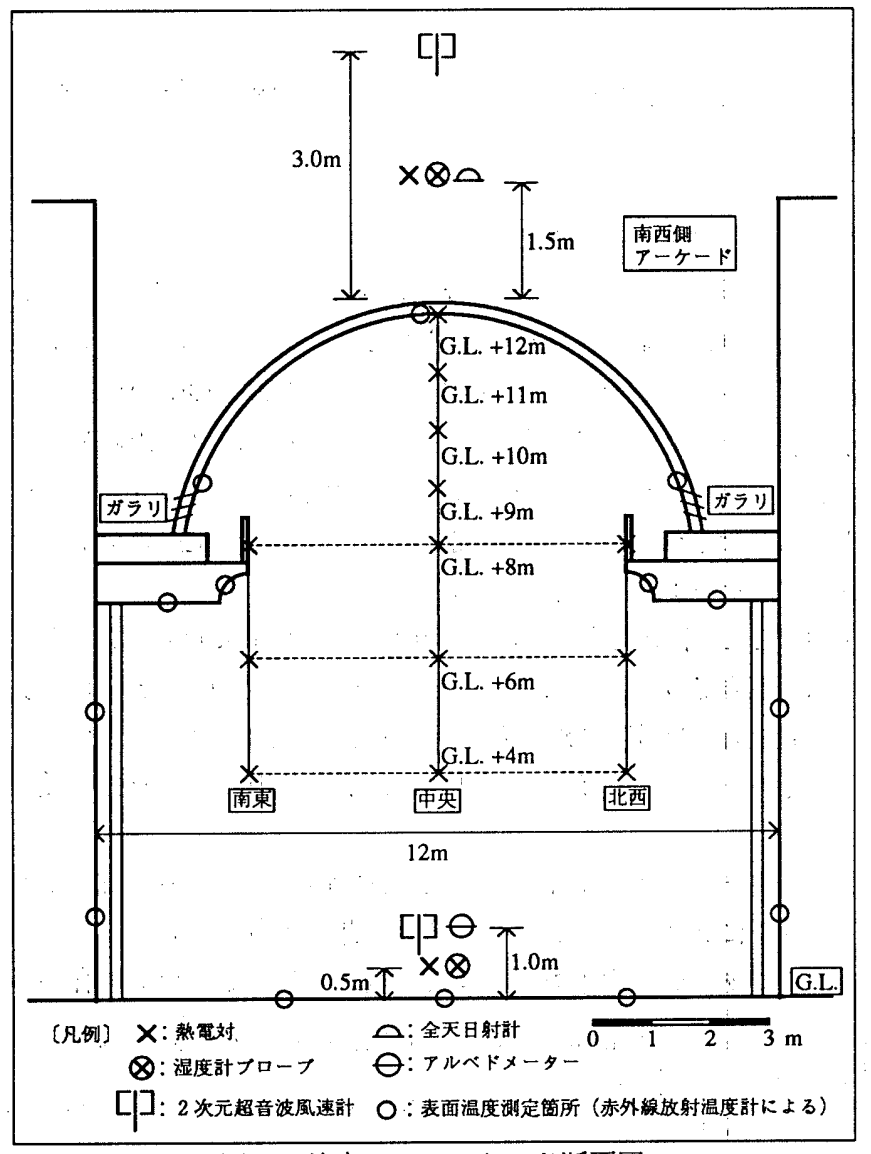

図 2 地点 2 のアーケード断面図
般車両の通行も見られることもあった。

愛媛県今治市はいわゆる瀬戸内海気候に属し, 高温, 小雨, 多 照, 弱風の気候特性を持つが，冬は比較的強風である ${ }^{6)}$ 。この気 侯のため, 現在のアーケードの原型と考えられる帆布製の天幕, すなわち「日覆い」が戦前より見られた》。また全国的にも早い 段階である ${ }^{8)}$ 昭和 20 年代後半からアーケードが建設され，現在で も，近箨の松山市や高松市などと並んでアーケードを持つ商店街 を数多く抱えている。

\section{3. 測定の概要}

\section{1 測定日時}

夏季の测定日時は1995年 8 月 8 日（火）夕方から 8 月 12 日 （土）早朝までであり，冬季の測定日時仗1996年 1 月 9 日（火） 夕方から1月12日（金）早朝までである。

\section{2 測定方法}

対象アーケードおよび商店街の形状および周辺地区の状況など を勘案して, 図 1 に示すように南西側から順に地点 1 より地点 4 までの測定地点を選定した。このうちアーケードおよび商店街の 形状などから最も代表的な測定地点と考えられる地点 2 について, 集中的に多くの項目を測定した（図 2)。なお地点 1 はアーケー ドの入口の影響を把握することを, 地点 3 は直交する車両通行可 能な道路との交差部分の影響を把握することを，地点 4 （図 3） は異なった形式のアーケードの状況を把握することを目的として 選定した。外気については地点 2 の上方, アーケードの外部・屋 上を測定点とした。なお，本稿では，アーケード内部で測定した 空気の温度を「気温」;アーケードの外部・屋上で測定した空気

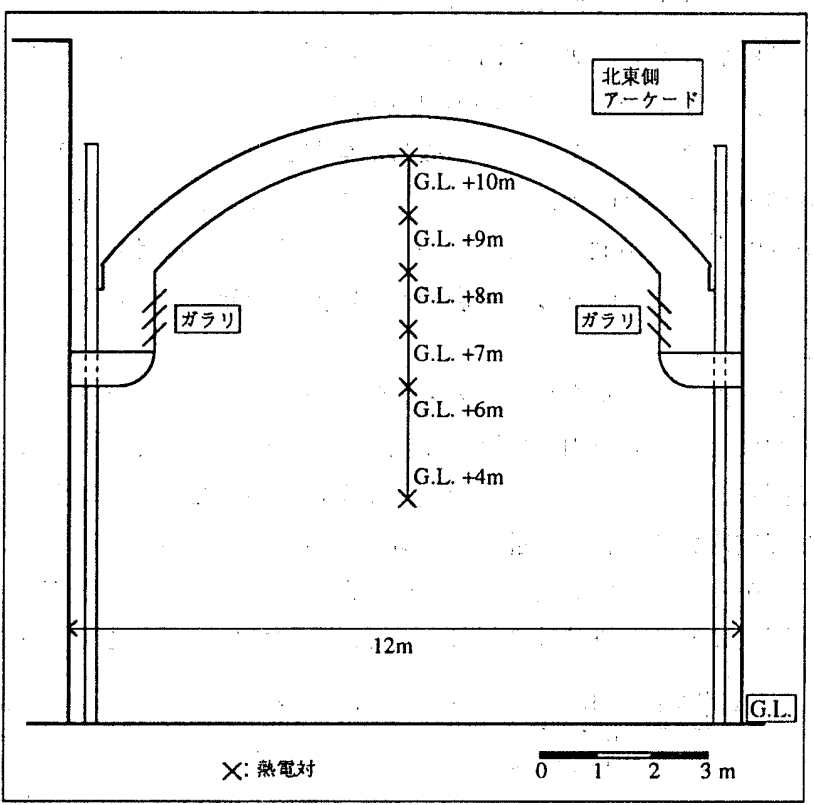

図 3 地点 4 のアーケード断面図 
の温度を「外気温」と記す。

な㧍，図 2 抢よび図 3 で，2枚描かれている屋根のうち，下側 が固定屋根であり，上側が可動屋根である。したがって，2枚の 屋根は可動屋根を移動させると重なるが, 通常は重なってはいな い。また, 図3のガラリは, 柱がない時には, 直接外部に接して いる。

各地点における測定項目とそれぞれで使用した測定機器などに ついて表 1 に示す。これらのデータは10分間隔で测定を行い,デー タロガーに記録させた。また，別に手動測定により，湿度および 風速を, 地点 1 から地点 3 まで, 9:00から21:00の間，2 時間おき に測った。同時に地点 2 においては，代表的な表面温度を放射温 度計で測定した（図 2）。

なお，8月9日および1月10日は商店街の定休日であり，全て ではないが多くの商店が閉店していた。

表 1 使用测定機器一覧

\begin{tabular}{|c|c|c|c|}
\hline 地点 1 & 測定項目 & 㑚定獲器など & 错考 \\
\hline & 温度 & 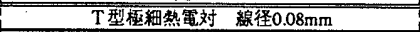 & 注 1) \\
\hline & マ゙ータロガー & 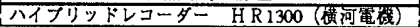 & \\
\hline 地点 2 & 测定項目 & 测定㙨器なと & 備考 \\
\hline & 温度 (中央) & T型权細熊電对 䍃径 $0.08 \mathrm{~mm}$ & \\
\hline & 温度 (南菓㑡) & T型極細郓電对 綳径 $0.08 \mathrm{~mm}$ & \\
\hline & 温度 (北西例) & 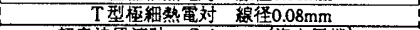 & \\
\hline 内部（地上） & 風向・風速 & 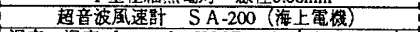 & \\
\hline & 湿度・温度 & 湿度·温度プローフ HMP35A (ロフイサラ) & \\
\hline & 温度 & 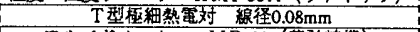 & \\
\hline & 日射 (7ルハF) & アルヘドメーターMR-22（英弘精㭘） & \\
\hline 外気（屋上） & 京向・風速 & 超音波風速部 SA-200 (海上電機) & \\
\hline & 湿度・温度 & 湿度・温度プーフ HMP 35A (ウフイサラ) & \\
\hline & 渴度 & T型極細熟電対 悢径 $0.08 \mathrm{~mm}$ & \\
\hline & 亘射 & 精密全天日射言十 MS-801 (英弘精独) & \\
\hline & データロガー & 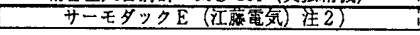 & i \\
\hline 地点 3 & 測定項目 & 测定供器なと & 㒂考 \\
\hline & 温度 & T型極細慜電对 湶径 $0.08 \mathrm{~mm}$ & 注 1) \\
\hline & データロロカー & 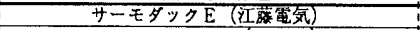 & \\
\hline & パンコン & PC-486 NOTE AV (EPSON) & I \\
\hline 地点 4 & 娜定項目 & 判定機器なと & 䚚考 \\
\hline & 温度 & T型轾練焣䉓対 線径 $0.08 \mathrm{~mm}$ & \\
\hline & テータロカー & $\mathrm{LT}-6 \mathrm{~A}($ タラム & 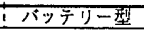 \\
\hline 手動測定 & & 测定璣器なと & 備考 \\
\hline & 通風乾湿培 & 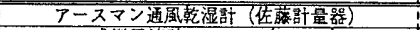 & 地点 \\
\hline & 風速㩽 & 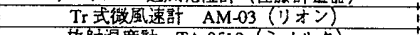 & 地点 1.2 \\
\hline & & & \\
\hline & 洋 2 & 行测時には，パソコン $\{98$ & 校。 \\
\hline
\end{tabular}

\section{3 気温の補正に関する検討}

気温の測定には，線径 $0.08 \mathrm{~mm}$ の $\mathrm{T}$ 型極細熱電対を用いた。この 場合熱電対は日射の影響を受けるため，補正を行う必要があり， 中村らは以下のような処理を行っている ${ }^{9)}$

すなわち，熱電対の裸線部分の長さが $5 \mathrm{~mm}$ 以下のものとそれ以 上のものに振り分け，次式に従い補正值を求め，測定値に加える ことにより補正を行う。

$5 \mathrm{~mm}$ 以下: $\Delta \theta=-1.45 \times 10^{-3}(J-64.5)$

$5 \mathrm{~mm}$ 以上: $\Delta \theta=-7.32 \times 10^{-4}(J-64.5)$

ここで，J：日射量 $\left[\mathrm{W} / \mathrm{m}^{2}\right]$ である。

ところで本測定では，アーケード内部の地上付近においてアル ベドメーターを用いて全天日射量を測定した。夏季におけるその 結果（困 4 ）よりアーケード内部の各熱電対が受ける日射量は夏 季においても最大で $160 \mathrm{~W} / \mathrm{m}^{2}$ 程度であり，この時補正值は，裸線 部分が $5 \mathrm{~mm}$ 以下であるとすると $-0.14 \mathrm{~K}, 5 \mathrm{~mm}$ 以上であるとす ると $-0.06 \mathrm{~K}$ である。また日射は直接熱電対に当たるのではなく， その前に一旦アーケードの屋根を通過している。よって本稿では， これらの影響を無視できると考え，日射による補正を行わないこ ととした。
また，外気温の測定にも熱電対を用いたが，日射量測定用の台 の下，太陽の直射の当たらない場所にセンサーを設置したので，

日射による補正を行わなかった。

\section{4 気象状況}

気象データとしては，松山地方気象台より今治地域気象観測所 （今治市大新田町 5-69-2）における，毎時気温，毎時日照時間， 毎時風向・風速および毎時降水量のデータを得た。

夏季の 8 月 8 日，8月 9 日および 8 月11日は概ね晴天であった が，8月10日は暴天であり，午前と午後の 2 回，気象デー夕には 現れない程度のわずかな降雨が見られた。

また冬季については，測定期間中は概ね晴天であった。

\section{4. 測定結果}

\section{1 夏季の測定結果}

図 4 に，夏季の場合のアーケード内部に扔ける地点 2 の地上か らの各高さの気温と外気温および日射量の経時変化を，10分間隔 の瞬時值で示す。図が小さいため細部の読み取りはできないが, 時間的変化の概要を知ることができる。

日射があると，アーケード内部の気温が上昇し，上層部と下層 部の温度差も大きくなるのがわかる。アーケード内部の最高気温 は，地点 1 の最上部（地上 $12 \mathrm{~m}$ ）で，8月 9 日11:00に測定された

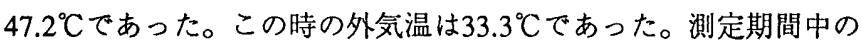
外気温は，最高が $37.0^{\circ} \mathrm{C}$ ，最低が $25.4^{\circ} \mathrm{C}$ であった。

8 月 10 日は前後の両日に比較して天気が悪く，日射量が少ない だけでなく，午前（10:00頃〜11:00頃）抢よび午後（13:00頃〜 14:00頃）の 2 回にわたって，気象観測值には現れない程のわずか な降雨があった。天候の影響で，この日は1日を通してアーケー ド内部の気温が低いだけでなく，上下の温度差も小さかった。

日射があると，16:30頃〜17:30頃にアーケード内部の地上の日射 量が大きな值を示すのは，商店街の中にたまたま1戸分の空き地 があり，その部分から太陽の直射が当たっていたことによる。冬 季にはこの現象は見られなかった。

\section{2 冬季の測定結果}

図 5 に，冬季の場合のアーケード内部に扔ける地点 2 の地上か らの各高さの気温と外気温および日射量の経時变化を，10分間隔 の瞬時値で示す。

アーケード内部の最高気温は, 地点 2 の最上部（地上 $12 \mathrm{~m}$ ）で,

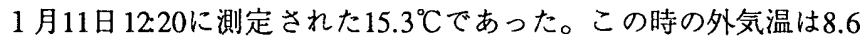
○であった。測定期間中の外気温は, 最高が $11.3^{\circ} \mathrm{C}$, 最低が $1.1^{\circ} \mathrm{C}$ であった。

日射があると，アーケード内部の気温が上昇し，上層部と下層 部の温度差が大きくなることは，夏季の場合と同様であるが，そ の度合いは夏季の場合より少ないことがわかる。これは, 端的に は日射量に表れている。すなわち, 晴天日の屋上の水平面日射量 が冬季では夏季の約 $2 / 3$ と少なくなり，アーケード内部の地上の 水平面日射量は冬季では夏季の $1 / 2$ 以下と，さらに少なくなって いる。冬季は日射量そのものが少なくなっている上に, 太陽高度 が低いため，周辺の建物に遮られるなどして，アーケード面を透 過するエネルギーが小さくなり, その結果, ア一ケード内部の気 
温に及ほす影響も少なくなったと解される。

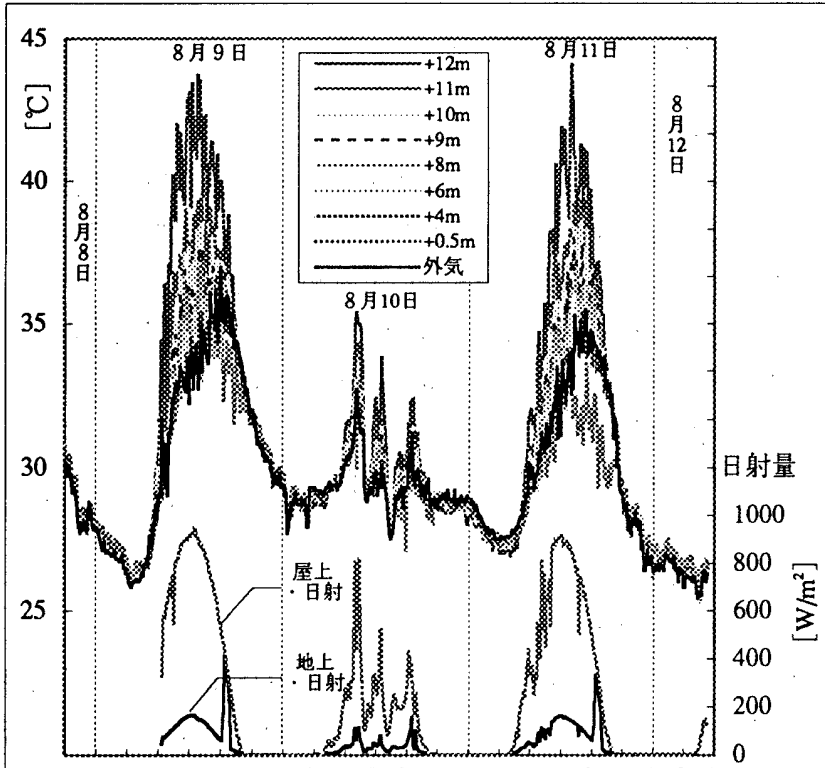

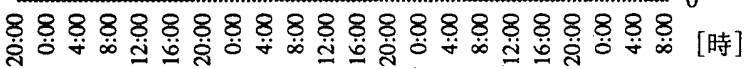

図4夏季の地点 2 の気温と外気温および日射量

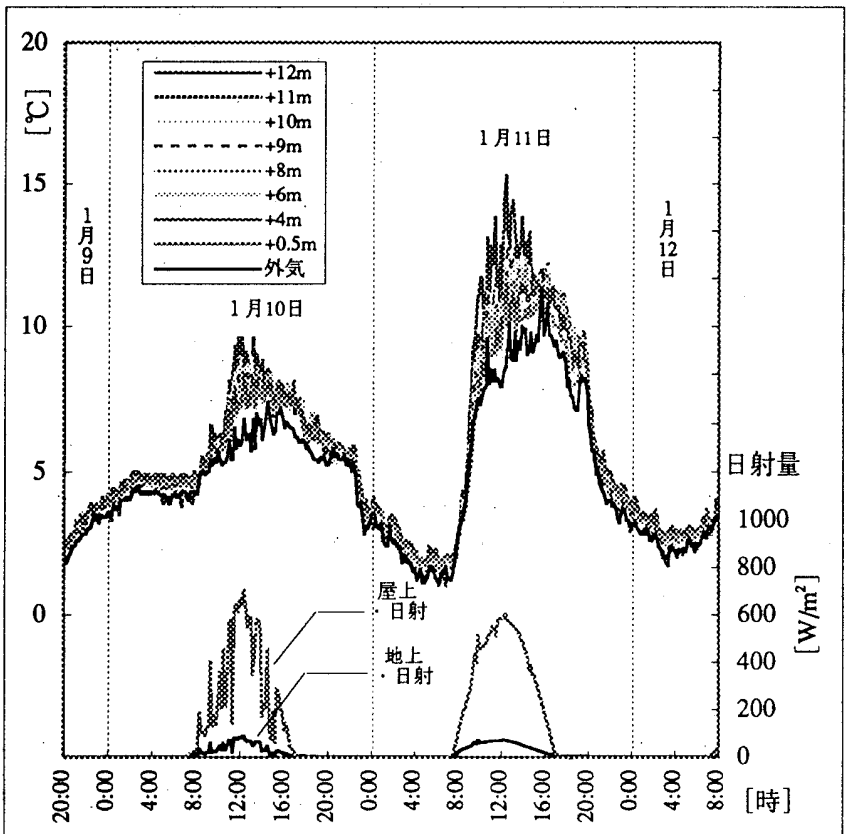

図 5 冬季の地点 2 の気温と外気温および日射量

\section{5. 考察}

\section{1 夏季の気温分布性状}

アーケード内部の地点 1 から地点 4 までの垂直方向への気温分 布を，8月11日の9:00から19:00まで2 時間おきに図6に示す。維 軸が地上からの高さ，横軸が温度である。縦軸上の「外気」は屋 上で測定した外気温である。2 時間おきの時刻の選択は，測定を 行った商店街を人々が利用する時間帯を考慮して行った。加えて， 参考として同日の正午12:00および梁夜23:00の垂直分布を示す。

図 7 には，図6と同じ時刻で, 地点 2 に扔けるアーケード内部 の断面における気温分布を示す。

（1）垂直方向への気温分布
アーケード内部の垂直方向への気温分布を示す図 6 から，以下 の特徽が指摘できる。

(1)夏季は，日中から夕刻にかけて，地上 $0.5 \mathrm{~m} の$ 気温は外気 温よりも低い。

(2)日中の気温は上方ほど高い分布を示している。

(3)日中は地上 $12 \mathrm{~m}$ の気温が特に高く, 中でも地点 1 が著し く高い。

(4)日中の垂直方向への気温分布は，測定地点によって形は 変わらないが, 值が変わっている。

(5)夜間は垂值方向への気温分布は解消する。

(1)については，12:00では地上0.5mの気温が外気温より高いが，

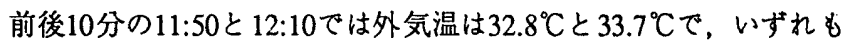
地上 $0.5 \mathrm{~m}$ の気温のほうが低くなっていた。表示が瞬時値であるた め，12:00にはたまたま値が高くなったもので，特に問題はない。

午後には地上 $4 \mathrm{~m}$ 以上の気温が外気温に近い値となり，地上 $0.5 \mathrm{~m}$ 気温が特に低いのは，両側の商店で冷房が行われ，室内の 冷気が漏出してきて地上 $0.5 \mathrm{~m}$ の気温の低下に加担している可能性

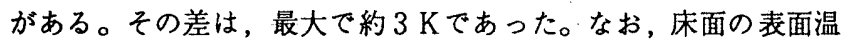
度は，いずれの測定時でも，地上 $0.5 \mathrm{~m} の$ 気温より床面の表面温度 の方が高かった。結局, 夏季はアーケード内部の地上 $0.5 \mathrm{~m} の$ 気温 は外気温より低い，というのが今回の調査で得られた実態である。

(2)については，午前から午後の15:00まで，垂直方向への気温分 布の傾きが強くなっている。最大で約 $6 \mathrm{~K} / 10 \mathrm{~m}$ の勾配である。こ れは, アーケードの屋根面を日射が透過して，屋根面および壁面 の上方から下方へかけて表面温度を上昇させ，それによる放射扔 よび対流の影響で，付近の気温を上昇させてアーケード内部空間 の上方に暖気が滞留したことによっている。17:00では，4 m以上 では垂直方向への気温分布がほとんどなくなり，日射の影響が衰 えていることを推察させる。

11:00，13:00および15:00で地上 $8 \mathrm{~m}$ 超えると垂直方向への気 温分布の傾きが急になるのが見受けられる。これは図 2 に示した ように，アーケード屋根の地上約 $9 \mathrm{~m}$ の高さにガラリのついた換 気用隙間があるので，それより上部が空気溜まりとなって垂直方 向への気温分布が急勾配になったものと思われる。

(3)については，別の测定からアーケード屋根の内側表面温は日 中で最高 $46.4^{\circ} \mathrm{C} に$ 達していたので，付近の気温もかなりの高温に なっていたはずで，それが地上 $12 \mathrm{~m}$ あたりに滞留したと推定され る。

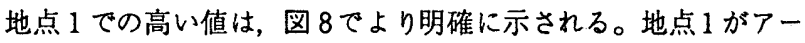
ケードの端部に近く，端部に設けられているアーチ状の妻壁があ るため，アーケード上層部の空気が滞留しやすくなり，結果とし て他の地点より気温が高くなったものと解される。地点 4 では， 上層部で高温空気の滞留が生じていないが，この地点（北東側アー ケード）では屋根の構造が南東側アーケードと異なり，屋根の重 なり部分の開口部が大きいため，換気が促進されたことによって いると解される。

(4)については，上記の屋根の隙間や下方の街路に面した開口か らのアーケード内部空間の換気の大小によって, 垂直方向への気 温分布が変わることなく，下方から上方まで一体として空気が動 いていることを推測させる。

(5)については，放射冷却によってアーケードの屋根面の温度が 

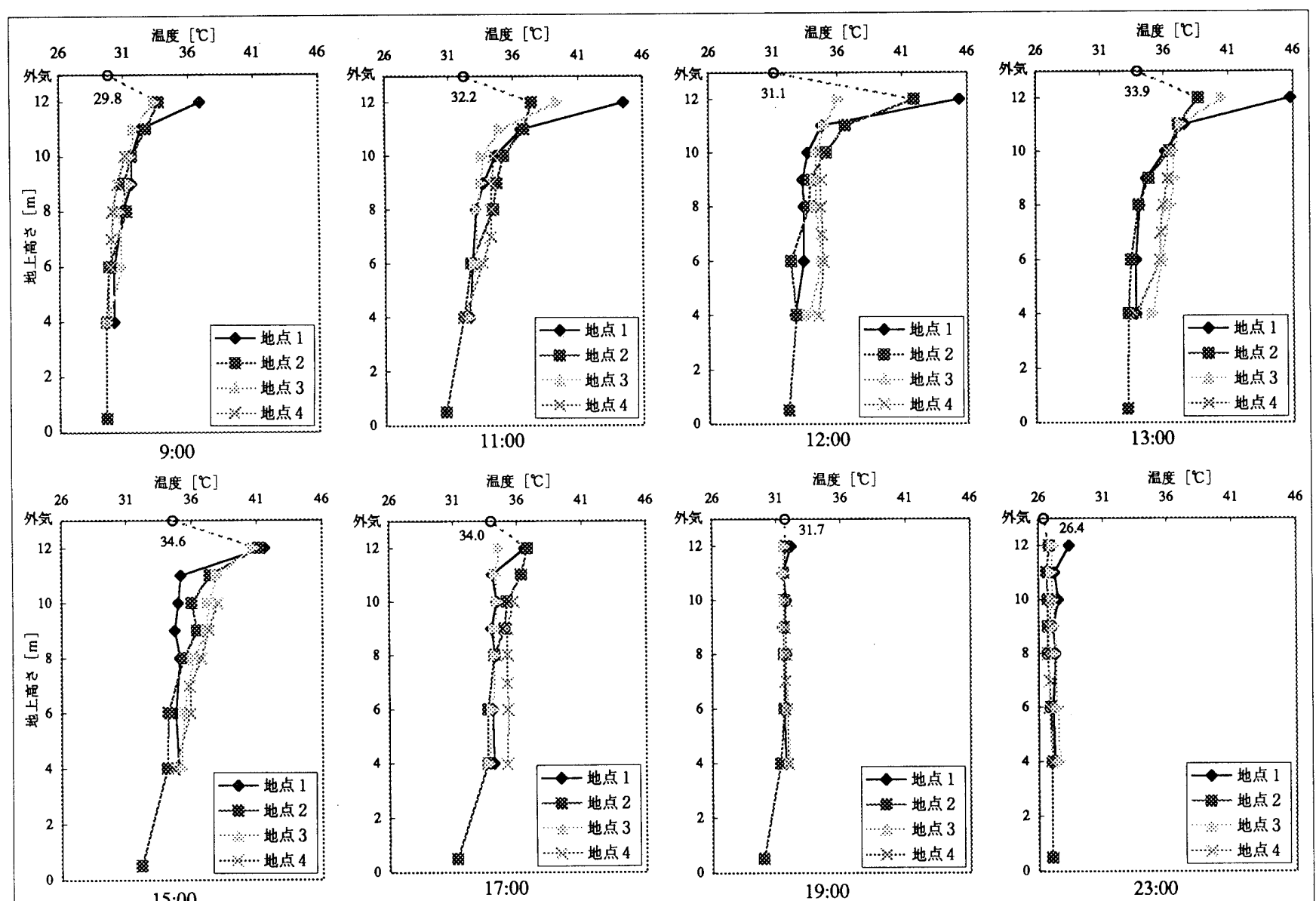

図6 夏季の各地点における気温の垂直分布の時間変化（8月11日）
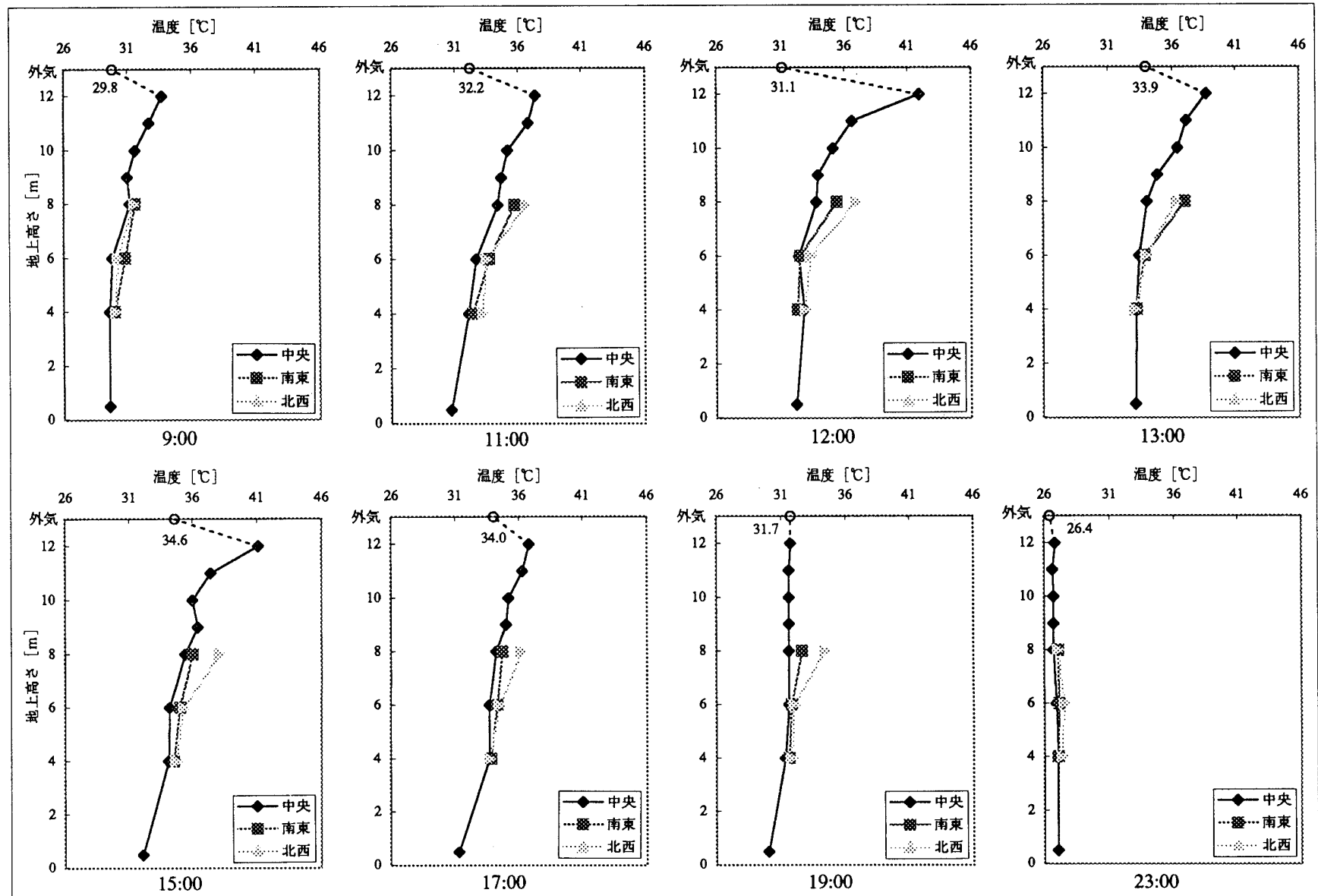

図 7 夏季の地点 2 に扔り気温の垂直分布の時間変化（8月11日） 
下がる一方, 外気温も下がり，その結果, 地点 1 の地上 $12 \mathrm{~m}$ を除 いては一様な気温になったと解される。なお，23:00には外気温が 地上 $0.5 \mathrm{~m}$ の気温より若干低くなっている。

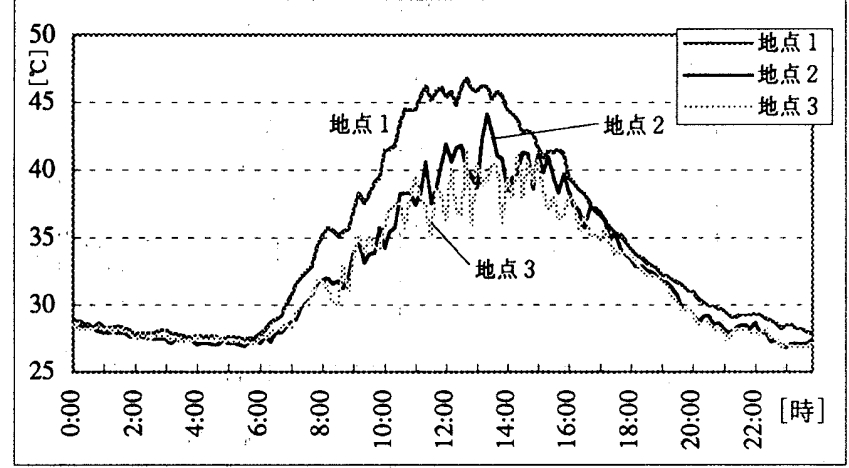

図 8 地点 1 から地点 3 の最上層部の気温（8月11日）

\section{(2) 断面における気温分布·地点 2)}

アーケード内部の断面における気温分布を示す図７から，次の 特徴が指摘できる。

(6日中から夕刻にかけて, 地上 $8 \mathrm{~m}$ で中央部より周辺部で 気温が高い。

図 2 に示すように，地上 $8 \mathrm{~m}$ の周辺部の気温測定点はアーケー ド屋根を支える手すり付の出っ張った通路に近い所に位置してい る。そのため，日中はそこへ日射が当たって付近の気温も上昇し ていると思われ，それが気温測定值に表れたものと解ざれる。

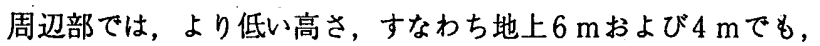
日中は中央部よりわずかながら高い時があるのが認められる。以 上のことから，日中のアーケード内部空間の空気流動は，アーケー ドの屋根を支える手すり付の出っ張った通路から下方の壁面へか けての，日射をうけたことによるいくらか高い気温の部分と，アー ケード断面の左右には中央の，上下には上から下までの部分とに 分かれて，生じていると想定される。すなわち，アーケード断面 のうち，左右の壁に接した上下方向の部分（左側方部），中央の 上下の上から下までの部分（中央部），右方の壁に接した上下方 向の部分（右側方部）という左右に三層構造をもった空気流動で ある。中央部ではアーケード通路に沿って空気が一体として流動 し，それが図 6 および図 7 に示した温度分布に表れていると解さ れる。

\section{2 冬季の気温分布性状}

冬季の測定では，夏季の測定の反省を踏まえて，データロガー

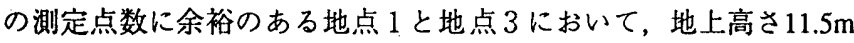
と $11.75 \mathrm{~m} の$ 気温測定点を追加した。これは，夏季の測定では最上 部の温度勾配が急激であることが判明し，より細かな測定が必要 であると考えたからである。

アーケード内部の地点 1 から地点 4 までの垂直方向への気温 分布を，1月11日の9:00から 19:00まで 2 時間掞きに図 9 に示す。 加えて, 参考として同日の正午12:00および梁夜23:00の垂直分布を 示す。

図10には，図 9 と同じ時刻で，地点 2 におけるアーケード内部 の断面に扔ける気温分布を示す。
（1）垂直方向への気温分布

アーケード内部の垂直方向への気温分布を示す図 9 から,以下 の特徵が指摘できる。

(1)冬季は, 日中から夜間にかけて, 地上 $0.5 \mathrm{~m} の$ 気温は外気 温よりも高い。

(2)日中の垂直方向への気温分布に，夏季ほどではないが， 傾きが認められる。

(3)地上 $12 \mathrm{~m}$ の気温は, 午前中から 13:00にかけて高い值を示 している。

(4)日中の垂直方向への気温分布は，測定地点によって形は 変わらないが, その值は変わっている。

(5)夜間の気温は，上方ほど低い分布を示す。

(1)については, 地上 $0.5 \mathrm{~m} の$ 気温は地上 $4 \mathrm{~m} の$ 気温とあまり变わ らないので，夏季と暴なって，両側の商店の室内の暖気が淏れ出 てきている形跡はない。

アーケードという覆いが内部の気温を外気温よりもいくらか高 く保つことに作用していることが考えられる。その差は，最大で

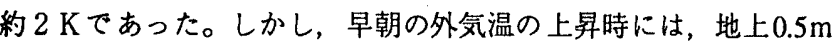
の気温の上昇が追いつかない傾向がうかがえる。

(2)については，日中の垂直方向への気温分布は，多少は上方ほ ど傾きが強くなっているのが認められる。最大で約 $2 \mathrm{~K} / 10 \mathrm{~m}$ の勾 配である。冬季の勾配は夏季の勾配の約 $1 / 3$ であるが，図 4 と図 5 を比較して冬季と夏季の地上での日射量の比が約 $1 / 3$ であるか ら，垂直方向への気温分布の傾きは地上での日射量に比例すると みてよい。

(3)については，地上 $11.5 \mathrm{~m} て ゙$ 気温の上昇が顕著でないので，そ れ以上の高さで高温空気が滞留していると思われる。

図11に，地点 2 での屋根表面付近の温度変化を示すが，これか ら日中の11:10および13:10で屋根の表面温が特に高く，外気温より $8 \mathrm{~K}$ 高くなっているのがわかる。それにともなってアーケード 内部の気温が上昇することになる。

(4)については，夏季と同様の傾向であるが，午前中から13:00ま で地点 1 の気温が他の地点より多少低く出ているのが注目される。 冬季の測定では日中の風向きの関係で, 地点 1 は, 外気がフーケー ド内部へ流れ込む時の最上流点になり，そのため他の地点の気温 よりも外気温に近く，すなわち低い目に出たことが想定される。

(5については，夏季には見られない特徵である。先の図11で， 午後から夜間にかけて，すなわち17:20，19:10および21:10に屋根 の表面温が外気温より最大で $3 \mathrm{~K}$ も低くなっているのがわかる。 放射冷却により表面温および表面に接した気温の低下が進行じて いる。

図12は，地点 2 夜間の気温変化を示したものである。この図 では判然としないが，全体的にアーケード内の上方はど気温が低 く，下方ほど気温が高いという結果になっている。放射冷却は一 般に冬季の方が夏季より大きく，屋根面での放射冷却の進行が急 速なため，上下の空気混合が十分に行われる間なしに上低下高の 気温分布を示した，と考えられる。

(2) 断面における気温分布（地点 2)

アーケード内部の断面における気温分布を示す図10から，次の 特徴が指摘できる。 


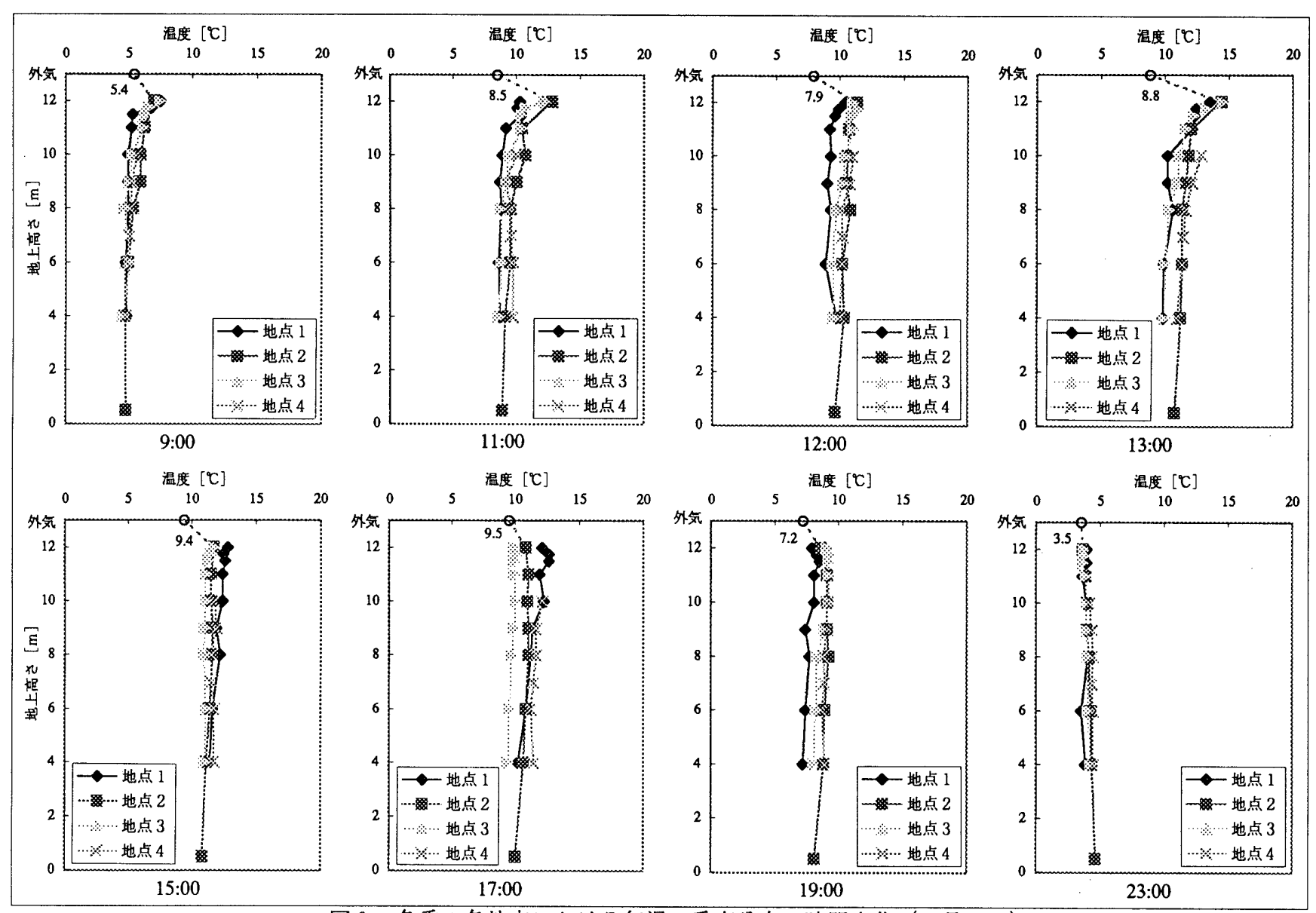

図 9 冬季の各地点に扔ける気温の垂直分布の時間変化（1月11日）
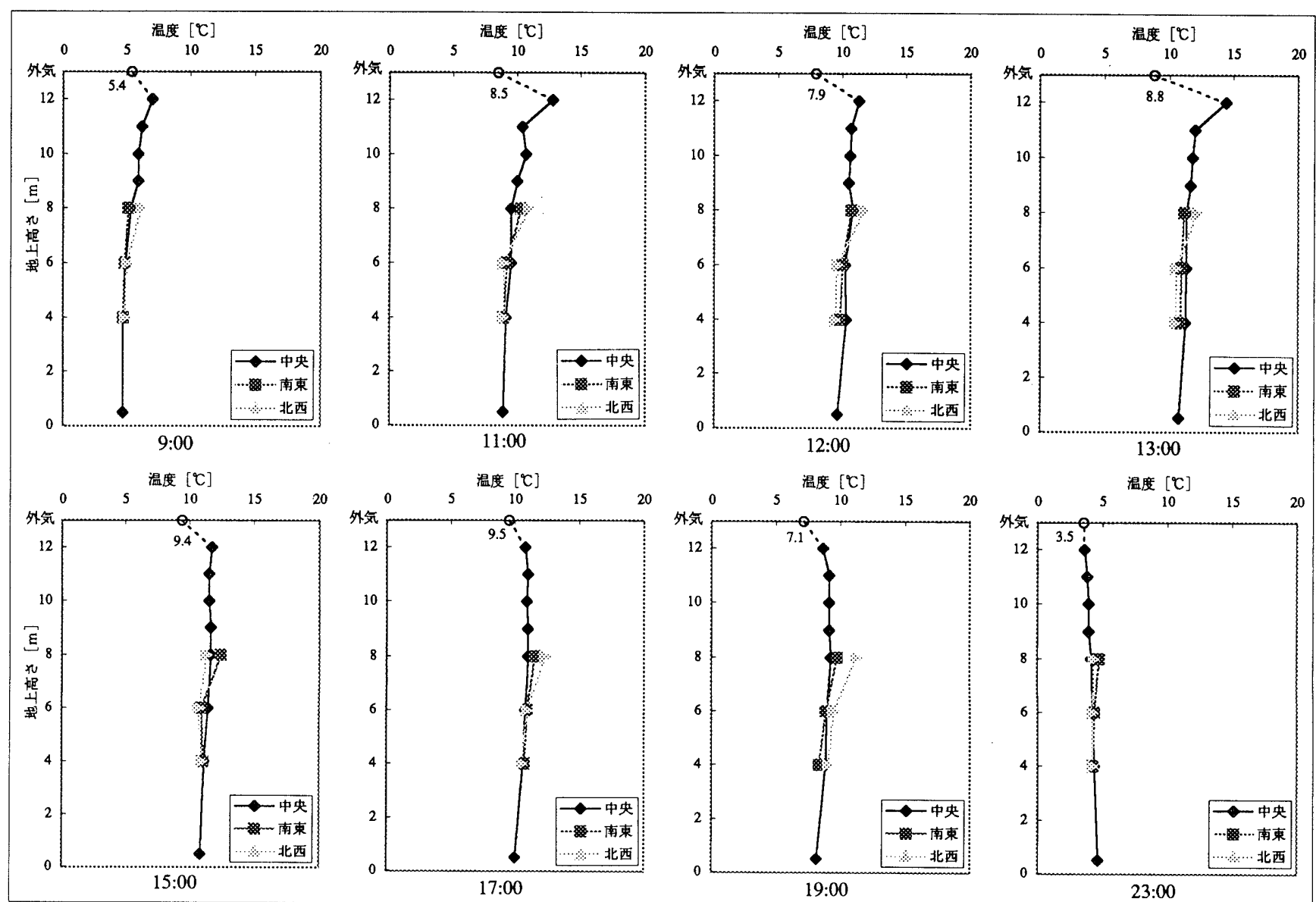

図10 冬季の地点 2 における気温の垂直分布の時間変化（1 月11日） 
(6)夏季ほどではないが，日中から夕刻にかけて，地上 $8 \mathrm{~m}$ で中央部より周辺部で気温が高い。

その程度はわずかである。しかし夏季と同様の傾向のため，基 本的には断面の左右に三層構造をもった空気流動があるものと想 定される。

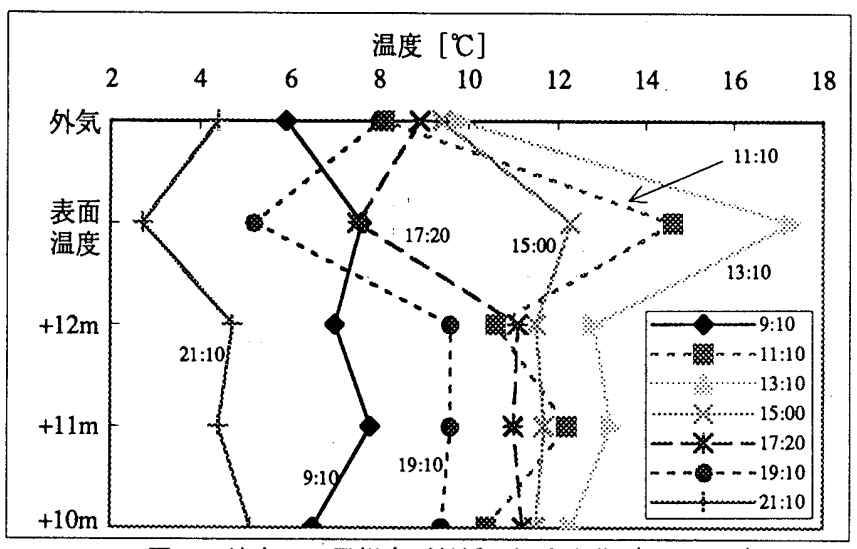

図11 地点 2 の屋根表面付近の温度変化（1月11日）

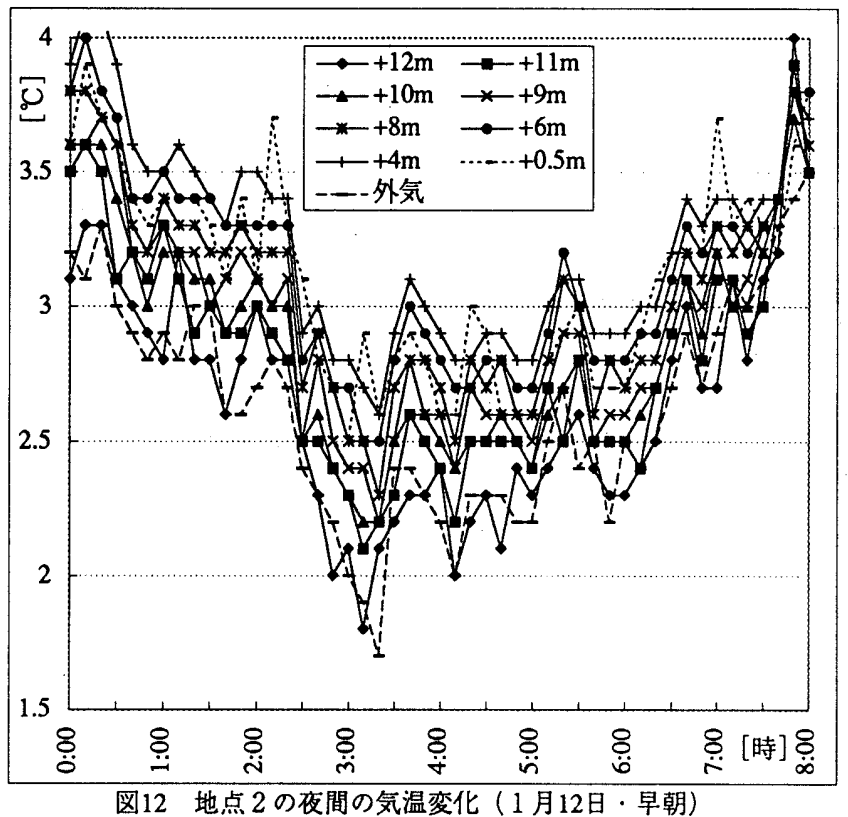

\section{3 換気の影響}

アーケードは水平方向に長い空間を形成しており，様々な形で 外部と接続している。外部のへ開口の度合いが, 内部の温熱環境 の形成に大きな影響を与えていた。すなわち，ガラリの位置，可 動屋根の固定屋根の隙間の大きさ, アーチ状の妻壁の存在, 内部 の流れ込む外気の風向などである。また, アーケード内部を囲む 建物表面の近傍では，アーケード内部空間の中央付近に比べ，空 気の流動が少なく，そのためアーケード内部では，中央および左 右の三層構造を持った空気流動が形成されていると推測された。
6. まとめ

アーケード空間の熱環境設計に資するため，温暖多照な瀬戸内 海気候地域に位置する全蓋型アーケードを対象とし，夏季と冬季 に分けて内部の気温分布を中心に熱環境測定を行った。得られた 結果は以下のとおりである。

1）アーケード内部空間の地上 $0.5 \mathrm{~m}$ の気温は，夏季の日中から夕 刻にかけては外気温より低かったが，夏季の夜間と冬季では 全日，地上 $0.5 \mathrm{~m}$ の気温が外気温より若干高かった。その差は 最大で，夏季の日中で約 $3 \mathrm{~K}$ ，冬季の日中で約 $2 \mathrm{~K}$ であった。 夏季の日中は，両側の商店の令房が行われている室内の冷気 が漏出してきている可能性がある。

2) 日中から夕刻にかけて，気温は上高下低の垂直分布を示す。 その勾配の大きさはアーケード内部空間の地上での日射量に ほほ比例する。

3 ）アーケード内部空間の上層部には高温の空気溜まりができる が，その厚さは $1 \mathrm{~m}$ 程度以下であった。

4) アーケードの延長方向で位置が変わっても, 垂直方向への気 温分布の形は変わらないが, 気温の值は変わる。值が変わる のは，それぞれの位置での換気量の違いによると考えられる。

5 ）日中のアーケード内部空間の空気流動は，側方部では日射を 受けた壁表面近くの高い気温の空気が支配的で，中央部をアー ケード内部の通路に沿って下方から上方まで一体となって空 気が流動するという，左右に三層構造をもった空気流動が想 定される。

謝辞：湘定にご協力頂いた協同組合今治常盤銀座会，今治常盤町中央商 店街振興組合，協同組合今治銀座振興会の皆㥞に多大なご迷惑を おかけしました。この場を借りて厚く御札申し上げます。

\section{<参考文献 $>$}

1）日本建築学会：アトリウムの環境設計，彰国社，1994.1.

2）吉野博，伊藤邦明，青笹健：アトリウムの温熱環境に関する文献調査 垂直温度分布と空間構成の関連，日本建築学会計画系論文集，第 483号, pp.63 72, 1996.5 .

3）田中棇，辻原万規彦，中村泰人，大塚順基：アーケード内部の温熱環 境に関する調查研究 その 1 実測概要, 日本建築学会近畿支部研究 報告集〈計画系〉，第36号，pp.273 276, 1996.7 .

4）河上健也，辻原万規彦，中村泰人：アーケード内部の温热環境に関す る調査研究 その 2 温度分布特性, 日本建榮学会近畿支部研究報告 集〈計画系〉，第36号，pp.277 280，1996.7

5）建設省：アーケードの取扱について，昭和 30 年 2 月 1 日付建設省発住 第 5 号, 1955.2.

6）潹石一夫：愛媛の気候，愛媛県文化振興財団，p. 162，1992.12.

7) 今治郷土史編さん委員会：写真加語る今治，今治市役所，p. $153,1989.3$.

8）辻原万規彦，大䆶健之，川崎雅史，小林正美：都市のアーケードデザ インに関する調查研究, 日本建築学会近畿支部研究報告集〈計画系〉, 第35号, pp.1185 1188, 1995.6.

9) 中村泰人，平岡久司，西村浩一：市街地空間における気温分布性状に 関する実験的研究，日本建築学会計画系論文報告集，第364号，pp.49 $\sim 50,1986.6$.

(1997年 9 月 8 日原稿受理, 1998年1月16日採用決定 